\title{
The Athol Syncline: tectonic evolution of a Westphalian A-B depocentre in the Maritimes Basin, Nova Scotia
}

\author{
B.C. Reed ${ }^{1}$, R.D. Nance ${ }^{1}$, J.H. Calder ${ }^{2}$, and J.B. Murphy ${ }^{3}$ \\ 1 Department of Geological Sciences, Ohio University, Athens, Ohio 45701, U.S.A. \\ ${ }^{2}$ Nova Scotia Department of Natural Resources, P.O. Box 698, \\ Halifax, Nova Scotia B3J 2T9,Canada \\ 3 Department of Geology, St. Francis Xavier University, \\ Antigonish, Nova Scotia B2G 2W5, Canada
}

Date Received May 25, 1993

Date Accepted November 8, 1993

\begin{abstract}
In the western Cumberland Basin, Nova Scotia, significant thickening of Westphalian A-B strata towards the axis of the Athol Syncline suggests that development of the syncline coincided with that of the depocentre. This contrasts with stratigraphic relations typical of the Late Paleozoic Maritimes Basin where thinning of Westphalian B strata indicates regional, Late Carboniferous erosion or non-deposition.

Post-depositional structural complications within the Athol Syncline include truncation of its southern limb by a nearvertical, east-west zone of strike-slip faulting. This zone, the Athol-Sand Cove Fault Zone (ASCFZ), has been correlated to the west with a complex zone of faulting exposed on the coast of Chignecto Bay where numerous normal, reverse and oblique-slip displacements suggest predominantly brittle deformation and changes in the sense of strike slip. To the east, the ASCFZ splays north into the Springhill coalfield where it is responsible for complex patterns of normal, reverse and strikeslip faulting within Westphalian A-B coal measures.

Major Late Carboniferous strike-slip faults adjacent to the Athol Syncline record dextral motion south of the Cumberland Basin (on the east-west Cobequid Fault) and possible sinistral motion along the basin's northwestern margin (on the northeast-southwest Harvey-Hopewell Fault). These faults are respectively interpreted to be synthetic and antithetic structures related to a regional dextral shear regime in which the east-northeast-west-southwest Athol Syncline and its associated depocentre formed in response to the direction of local compression during basin development. However, kinematic analyses indicate that post-depositional motion on the ASCFZ was predominantly sinistral. Development of the Athol Syncline is therefore interpreted to have been controlled by dextral, syndepositional transpression during the Late Carboniferous, whereas later, post-depositional displacement across the ASCFZ reflects predominantly sinistral transtension and may be related to the opening of the Fundy Basin which reversed the sense of regional shear during the Middle Triassic.
\end{abstract}

Dans la partie ouest du bassin de Cumberland en Nouvelle Écosse, un épaississement important des strates du Westphalien A-B vers l'axe du synclinal d'Athol suggère que le développement du synclinal a coïncidé avec celui du centre de déposition. Ceci contraste avec les relations stratigraphiques typiques du bassin des Maritimes du Paléozoïque tardif où l'amincissement des strates du Westphalien $B$ indique une érosion régionale ou une absence de déposition au Carbonifêre tardif.

Les complications structurales après déposition à l'intérieur du synclinal d'Athol comprennent la troncature de son flanc sud par une zone de faille de décrochement est-ouest quasi-verticale. Cette zone, la zone de faille d'Athol-Sand Cove (ZFASC), a été corrélée vers l'ouest avec une zone de faille complexe exposée sur la côte de la baie de Chignecto où de nombreux déplacements normaux, inverses et obliques suggèrent une déformation principalement cassante et des variations du sens de décrochement. Vers l'est, la ZFASC se divise vers le nord dans le bassin houiller de Springhill où elle est responsable d'un réseau complexe de failles normales, inverses et de décrochement dans les séquences houillères du Westphalien A-B.

Les failles majeures de décrochement du Carbonifere tardif adjacentes au synclinal d'Athol montrent un mouvement dextre au sud du bassin de Cumberland (le long de la faille de Cobequid d'orientation est-ouest) et peut-être un mouvement sénestre le long de la bordure nord-ouest du bassin (le long de la faille d'Harvey-Hopewell, d'orientation nord-est - sudouest). Ces failles sont interprétées comme des structures synthétiques et antithétiques liées à un régime régional de décrochement dextre responsable de la formation du synclinal d'Athol d'orientation est-nord-est - ouest-sud-ouest et du centre de dépôt associé en réponse à la direction de compression locale durant le développement du bassin. Cependant, des analyses cinématiques indiquent que le mouvement postérieur au dépôt le long de la ZFASC était principalement sénestre. Le développement du synclinal d'Athol est donc interprété comme ayant été contrôlé par une transpression dextre contemporaine au dépôt durant le Carbonifère tardif, tandis que le déplacement plus tardif, postérieur au dépôt, de la ZFASC reflète principalement une transtension sénestre et pourrait être liée à l'ouverture du bassin de Fundy qui a inversé le sens du cisaillement régional pendant le Trias moyen.

[Traduit par la rédaction] 


\section{INTRODUCTION}

Between 1985 and 1990, the Geological Survey of Canada, with assistance from the Nova Scotia Department of Natural Resources, conducted a high resolution seismic survey in the western Cumberland Basin to better define the stratigraphy and structure of the basin's coal-bearing strata (Calder and Bromley, in press). The seismic data revealed a major dislocation of the coal-bearing strata which was subsequently correlated to the west with a fault zone that deforms sedimentary rocks of the Upper Carboniferous Cumberland Group along Chignecto Bay, and to the east with faults that disnupt the Springhill coalfield (Ryan et al., 1990a, b). Calder (1984) had previously documented the deformation of coal-bearing strata at Springhill, but was uncertain of the westward continuation of the faults responsible. The major east-west trending zone of dislocation (Fig. 1) includes the Athol, Sand Cove and Sand River faults, and has been termed collectively the Athol-Sand Cove Fault Zone (ASCFZ; Calder and Bromley, 1988). Delineation of the ASCFZ was one of the most significant revisions by Ryan et al. (1990a, b) to earlier maps of the Cumberland Basin by Bell (1938) and Shaw (1951).

Inland, the faults truncate the southern limb of the Athol Syncline, a Late Carboniferous depocentre that occupies much of the western Cumberland Basin and constitutes the largest coal basin in mainland Nova Scotia (Calder, 1985). Seismic profiles of this syncline (Calder and Bromley, in press) show considerable thickening of Upper Carboniferous strata towards the synclinal axis, suggesting that deformation and deposition were penecontemporaneous. The relationship of the ASCFZ to the development of the Athol Syncline and the western Cumberland Basin consequently plays an important role in basin analysis and coal resource evaluation. It is this relationship, as recorded in the deformational history of the ASCFZ, that forms the subject of this paper.

\section{Geologic Setting}

The Cumberland Basin (Fig. 1) is a southern component of the much larger Maritimes Basin of eastern Canada. This larger basin has been interpreted to have developed within an intracontinental transform zone, characterized by transpressional deformation and rapidly subsiding extensional sub-basins (e.g., Bradley, 1982; Martel, 1987; Gibling et al., 1987). The Maritimes Basin originated in the Middle to Late Devonian during waning stages of the Acadian orogeny (e.g., McCutcheon and Robinson, 1987) when the Meguma Terrane of southern Nova Scotia was accreted to the inboard Avalon Composite Terrane (Keppie, 1989).

The Cumberland Basin forms a large $\left(5000 \mathrm{~km}^{2}\right)$, east- to northeast-trending synclinorium that occupies much of northwestern mainland Nova Scotia and adjacent parts of New Brunswick (Ryan et al., 1987). Within the basin, several northeast-trending synclines are separated by anticlines formed by evaporite diapirs of the Lower Carboniferous (Visean) Windsor Group. The basin is bounded to the south by the Cobequid Highlands and to the west by the Caledonia Highlands of southern New Brunswick (Fig. 1). To the east, Upper Carboniferous
(Westphalian D-Stephanian) strata of the Pictou Group unconformably overlie older strata of the Windsor, Mabou, and Cumberland groups (Barss and Hacquebard, 1967). The northern basin margin lies beneath the Northumberland Strait.

Carboniferous strata constitute the majority of the basinfill which consists of Upper Devonian to Lower Permian sedimentary rocks of mostly continental origin (Ryan et al., 1987). According to the revised stratigraphy of Ryan et al. (1991), Upper Carboniferous strata in the Cumberland Basin predominantly comprise conglomerates, sandstones and shales with locally important deposits of coal and evaporites. The abundance of Westphalian A and B sediments within the Cumberland Basin (represented by the Cumberland Group; Dolby, 1991) suggest that the basin was a major depocentre at that time, in contrast with most other parts of the Maritimes Basin where thinning of Westphalian B sediments suggests regional erosion or non-deposition.

The western Cumberland Basin lies adjacent to two major faults, the east-west Cobequid and northeast-southwest HarveyHopewell faults, that are likely to have played an important role in basin development and deformation. The strike-slip Cobequid Fault flanks the Cumberland Basin south of the Cobequid Highlands Massif, deforming the southern part of the Maritimes Basin. The fault is the surface expression of the terrane boundary separating the Avalon Composite Terrane of northern mainland Nova Scotia from the outboard Meguma Terrane. Dextral offset of up to $200 \mathrm{~km}$ along this boundary has been suggested for the Late Carboniferous (Keppie, 1982; Donohoe and Wallace, 1985) with movement continuing well into the Permian.

The Harvey-Hopewell Fault parallels and deforms the northwestern edge of the Cumberland Basin in southern New Brunswick (Gussow, 1953), and is thought to be truncated by the Cobequid Fault beneath the Bay of Fundy. The history of movement and sense of displacement on this fault are uncertain. However, a component of sinistral offset, suggested by Webb (1963) on the basis of isopach maps and clast-size analysis of Mississippian Hopewell Group conglomerates, is consistent with the orientation of adjacent en échelon folds (Fig. 1). These folds affect Westphalian A sediments, but predate those of Westphalian C-D age, suggesting that movement occurred during the Westphalian B.

\section{Structures within the CumberLand Basin}

\section{Athol Syncline}

The structure of the region is dominated by the Athol Syncline, a sub-basin occupying much of the western Cumberland Basin (Fig. 1). Seismic profiles (Calder and Bromley, in press) demonstrate that the thickness of basin-fill strata increases towards the axis of the Athol Syncline, suggesting that the syncline developed syndepositionally. The syncline is slightly asymmetric with its steepest limb to the north, adjacent to the Minudie Anticline. The synclinal axis plunges gently to the west-southwest. These seismic profiles also suggest that a major east-west fault zone (the ASCFZ) truncates the southern limb of the Athol Syncline and is coincident with major faults subparallel to the 


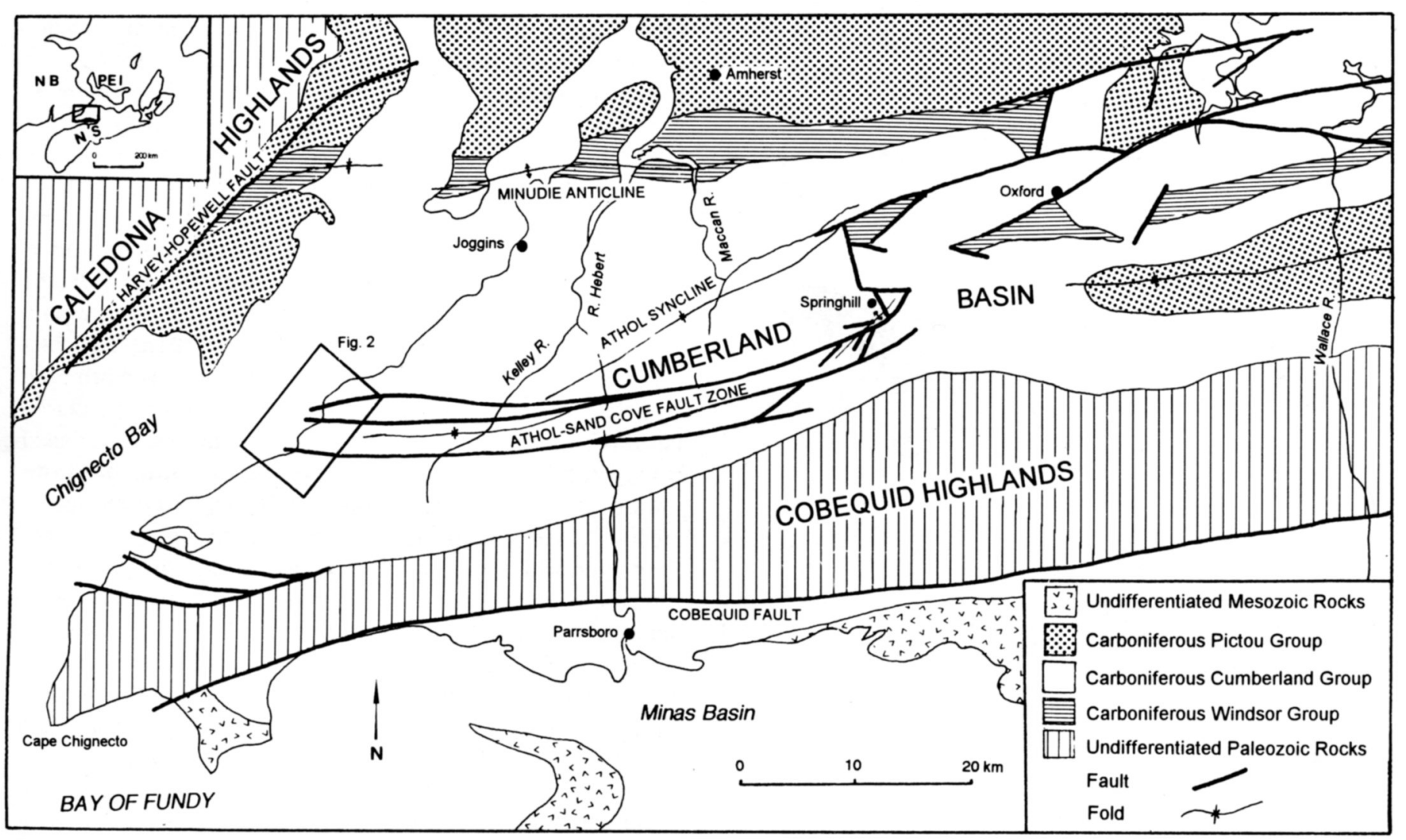

Fig. 1. Simplified geology of the western Cumberland Basin (after Calder, 1991).

Springhill Anticline. Strike-slip movement along this fault zone is suggested by slickensided shear planes along Kelley River, by anomalous juxtapositioning of strata near River Hebert, and by the deformation of the Springhill Anticline (Calder, 1985). Like other major fold structures within the Cumberland Basin, the en échelon orientation of the Athol Syncline is consistent with dextral motion on east-west fault systems active at the time of its formation. However, sinistral offset of the poorly defined synclinal axis across the fault zone suggests a younger episode of left-lateral movement on the ASCFZ.

\section{The Athol-Sand Cove Fault Zone}

The Athol, Sand Cove, and Sand River faults are exposed along a $5 \mathrm{~km}$ coastal section of Chignecto Bay some $25 \mathrm{~km}$ south of Joggins in the Sand Cove area (Fig. 2). The faults define a major zone of strike-slip movement that deforms sediments of the.Westphalian B Ragged Reef Formation along the coast, and sediments of the Westphalian A-B Springhill Mines and possibly early Westphalian C Malagash formations progressively eastward. The Ragged Reef Formation exposed in the coastal section comprises coarse conglomerates interbedded with finer-grained lithic arenites and thin beds of siltstone and shale with local coalified plant remains. Numerous minor faults deform these rocks resulting in a complex array of structures that form a broad fault zone (ASCFZ). The zone of deformation associated with the ASCFZ is about $20 \mathrm{~km}$ wide and at least $150 \mathrm{~km}$ long, and extends from the coast of Chignecto Bay eastward across the Athol Syncline and into the Springhill coalfield
(Fig. 1). It may be continuous with east-west "basement" faults of the Claremont Anticline, east of Springhill, and with the St. George-Saint John Fault in southern New Brunswick (McCutcheon and Robinson, 1987).

Faulting along the coast is predominately extensional with normal, reverse, oblique, and rotational components of motion. Brittle faulting prevails, suggesting that the structures developed at shallow crustal levels although barite and galena vein fillings and salt springs are associated with the ASCFZ at Springhill. The upward-diverging geometry of the exposed fault zone resembles that of a negative flower structure (Harding, 1985), and may be rooted to ductile deformation at depth. Overall displacement across the fault zone is unknown. Offset on individual faults exposed along the coast is typically no more than a few meters. The combined offset across the entire fault zone, however, is substantial (Ryan et al., 1990a), with the seismic data suggesting a net down-to-the-north dip dispacement of several hundred metres (Calder and Bromley, in press).

\section{Springhill Anticline}

Calder (1984) described the structural features of the Springhill coalfield exposed in open pit and underground coal mines and in drill cores. The Springhill Anticline is the dominant structural feature within the coalfield; its axis plunging southwest at approximately $10^{\circ}$. Several poorly defined anticlines and synclines parallel the main structure, and several extensional graben faults cross the crest of the main fold parallel to its axis. Hence, the Springhill structure resembles both a 


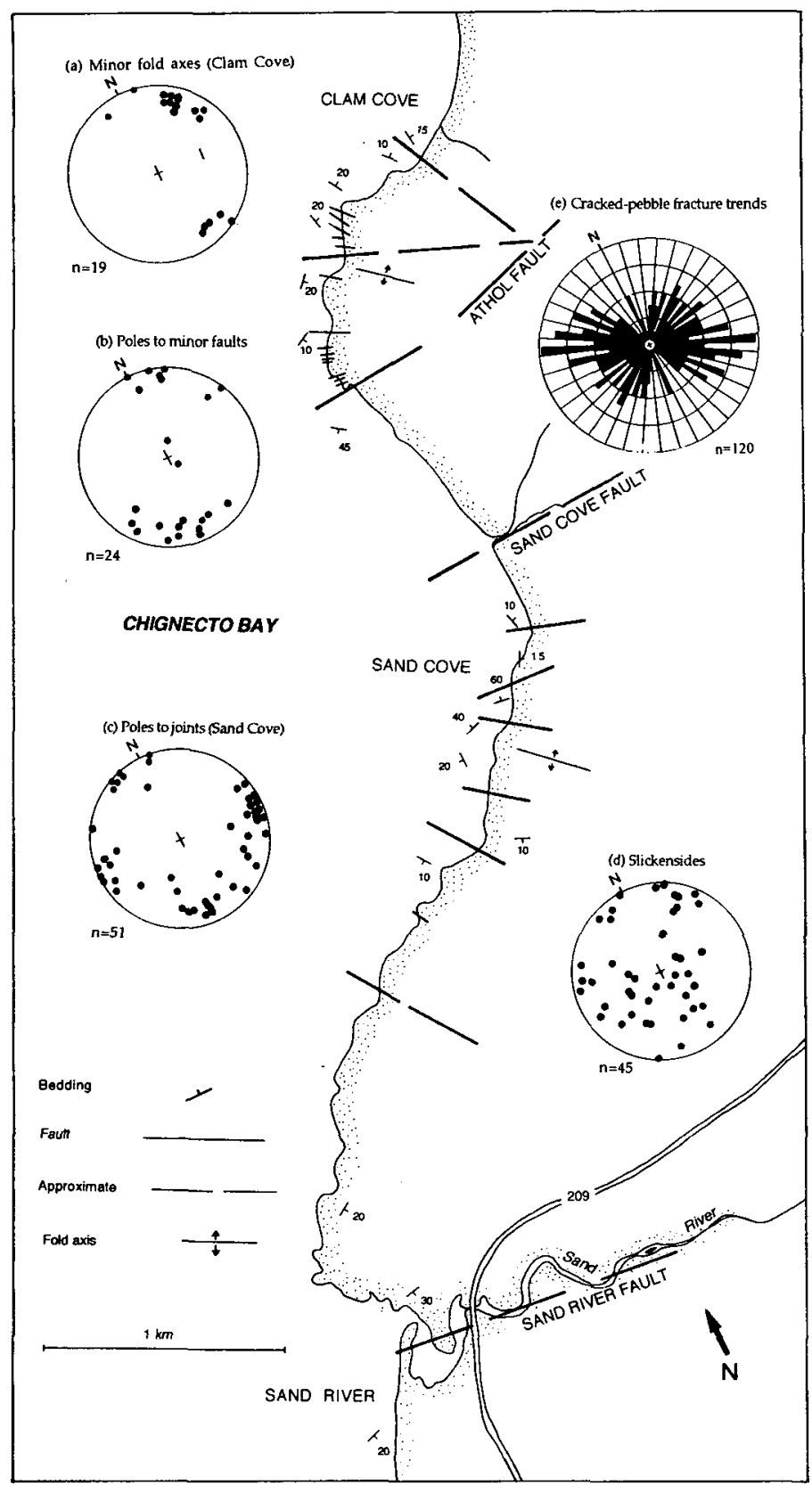

Fig. 2. Structural map of the Clam Cove-Sand Cove area. Equal-area stereographic projections of (a) minor fold axes at Clam Cove, (b) poles to fault planes at Clam and Sand coves, (c) poles to joints at Clam Cove, and (d) slickensides at Clam and Sand coves. (e) Rose diagram (at $5^{\circ}$ intervals) of cracked-pebbles fracture trends at Sand Cove. Note oblique orientation of geographic north. $n=$ number of data points in each sample.

collapsed anticline and a negative flower structure in profile, since the geometry of the structure at depth is not known.

Normal faulting is the most common style of fracturing in the Springhill coalfield but can be a component of scissor faulting in which changes in the sense of slip from normal to reverse occur across the fault hinge (Calder, 1984). Other styles of faulting include strike-slip faults, normal cross-faults, bedding-plane faults and thrust faults. Gentle folding of strata within fault blocks and the offset of fold axes in the Novaco open-pit mine suggests that some ductile or syndepositional deforma- tion occurred prior to faulting. Poorly developed minor folds occur adjacent to some fault planes (where they are presumably related to fault drag), and rare chevron folds occur in compression zones between thrusts and cross-faults.

\section{Diapirs}

Intermittent diapirism of Visean Windsor Group evaporites is an important component of deformation within the Cumberland Basin and was originally believed to be responsible for the folding of Westphalian basin-fill strata. The deterioration of coal seams across the present axis of the Springhill Anticline was also thought to be due to diapirically induced uplift (Hacquebard et al., 1967), but has since been attributed to the coincidence of progressive depositional onlap of coal seams towards the basin margin (Calder, 1991). Dolby (1988) recovered reworked Visean spores in coals of the Springhill Mines Formation which suggest that Windsor Group strata were being eroded during the early Westphalian B. Thus, the bulk of diapirism is believed to have occurred before the late Westphalian (Calder, 1991) and is not thought to have significantly deformed subsequent strata (Bell, 1944). Overturned beds of the Windsor Group unconformably overlain by gently dipping Cumberland Group strata near Pugwash (Ryan et al., 1990b), suggest similar timing for diapirism in the eastern Cumberland Basin. Diapirism strongly influenced Visean to early Westphalian strata adjacent to the western Cumberland Basin, as witnessed by steeply dipping and folded beds exposed near the village of Minudie and in quarries south and east of Amherst. Steepening of the Cumberland Group strata of the Athol Syncline adjacent to the Black River Diapir, near Oxford, and the salt-cored Minudie Anticline (Fig. 1) may reflect subsequent diapirism, but is thought to be related to poorly defined faults north and northwest of Springhill. Nevertheless, diapirism and/or salt withdrawal, which have long been linked to pre-exisiting basement faults (e.g., Howie and Cumming, 1963), are likely to have played a role in amplifying younger tectonic structures.

\section{KINEMATIC DATA AND INTERPRETATION}

Detailed kinematic data on the ASCFZ are provided by excellent exposure of the Ragged Reef Formation along Chignecto Bay north of Sand River (Fig. 2). For the purpose of analysis, the section was divided into northern and southern subareas because of differences in the intensity of deformation between Clam Cove and Sand Cove. Kinematic data were also collected from road-cuts along Windam Hill Road and stream outcrops in Lynn Mountain Brook, south and southwest of Springhill, and from quarries and scattered outcrops elsewhere within the western Cumberland Basin. A review of data collected by Calder (1984) from the Springhill coalfield is included for comparative purposes.

\section{Fault analysis}

Analysis of fault planes in both the northern (Clam Cove) and southern (Sand Cove) subareas indicates that the ASCFZ here is a steeply dipping structure striking roughly east-west. Fault pole orientations along the coast plunge gently south (Fig. 
2b). Faulting is more pervasive in Clam Cove where steeply dipping normal-oblique faults predominate although some show reverse displacements. Many of the larger faults exposed along the coast are sinuous and occur in association with minor cross faults and reverse faults or closely spaced synthetic and antithetic joints.

At the eastern end of the ASCFZ, major normal faults commonly bound grabens on the crest of the Springhill Anticline and terminate in splays and flexures (Calder, 1984). Faults in the Springhill coalfield strike northeast and dip between $55^{\circ}$ and $75^{\circ}$ towards the fold axis. Most of these faults have experienced some degree of oblique slip, and throws are on the order of tens of metres. Minor folding attributed to fault drag locally occurs adjacent to the fault planes but, in most cases, contacts between faults and bordering strata are abrupt. Associated strikeslip faults trend northeast, roughly parallel to the major normal faults, and are aligned at about $60^{\circ}$ to the normal cross-faults. Thrust faults related to bedding-plane slip locally occur at compressive junctures between major normal faults. These thrusts disrupt the normal cross faults and appear to be the youngest structures. The direction of thrusting is toward the north $\left(010^{\circ}\right)$, subparallel to the strike of minor normal faults.

The overall geometry of extensional faulting in the Springhill Anticline suggests collapse of the structure subsequent to its formation. Although likely cored by salt, the complex pattern of faulting and the contrasting senses of fault movement argue against passive collapse of the anticline in response to salt withdrawal. In the absence of data at depth, the downward-converging fault configuration (Calder, 1984) resembles a negative flower structure (Harding, 1985), consistent with postdepositional sinistral shear.

\section{Fold analysis}

Although there is little evidence in outcrop for ductile deformation on the coast of Chignecto Bay, minor folding locally occurs in less competent hangingwall or footwall strata adjacent to faults at Clam Cove. The axes of these minor folds plot in two clusters (Fig. 2a). The majority are drag folds related to east-west faults and plunge gently northeast subparallel to the Athol Syncline. Folding may therefore have locally accompanied faulting during the middle to late Westphalian. The second cluster of fold axes plunge gently south-southeast, subparallel to the axis of a large faulted antiform exposed south of Clam Cove (Fig. 2). A second fault-bounded antiform exposed further south in Sand Cove plunges gently northwest.

The orientation of the two sets of fold axes suggests contrasting movement senses on associated faults. Whereas the majority are consistent with a phase of dextral shear on eastwest faults of the ASCFZ, the orientation of the second set (and that of the faulted antiformal structures) suggests sinistral shear on intervening faults of the fault zone

In the Springhill coalfield, the axis of the Springhill Anticline plunges southwest at about $10^{\circ}$. Calder (1984) describes gentle folding of strata within fault blocks exposed in the Novaco open-pit mine, including minor "drag" folding adjacent to faults, and rare chevron folding in compression zones between thrust and cross faults. Fold axes are usually subperpendicular to major bounding faults (suggesting a significant component of strike slip) and plunge east to northeast. Offset of fold axes by the faults suggests that faulting largely postdates folding.

\section{Joint analyses}

Jointing is well developed throughout the western Cumberland Basin. Near-vertical joints in Clam Cove and Sand Cove strike north to northeast with a subsidiary east-west set at Sand Cove subparallel to the ASCFZ (Fig. 2c). Joint orientations taken from outcrops along Windam Hill Road and Lynn Mountain Brook, near Springhill, similarly strike northeast. Joints associated with faults in the Springhill coalfield (Calder, 1984) are oriented east-west, similar to those of the subsidiary joint set at Sand Cove.

The predominance of northeasterly striking joints along the length of the ASCFZ suggests regional northwest-southeast extension, consistent with sinistral motion on the fault zone.

\section{Slickenside analysis}

Slickensides on fault surfaces in Upper Carboniferous rocks throughout the western Cumberland Basin range in orientation from subhorizontal to steeply plunging. The majority of slickensides in both the Clam Cove and Sand Cove subareas plunge gently northeast, with lesser groups plunging steeply southeast and moderately west (Fig. 2d).

The wide scatter of slickenside orientations record a range of movement directions that probably reflect both the variety of fault types associated with zones of strike-slip deformation and the complex movement history of the ASCFZ. The latter is documented on numerous faults along the Chignecto coast where single fault surfaces may contain growth fibres that record various slip directions. Although the measured data is scattered, gently plunging slickensides constitute the majority of orientations, consistent with the predominance of strike-slip motion. Steeply southeast- and moderately west-plunging slickensides are consistent with the data on minor folding and indicate important components of dip-slip and oblique-slip motion, respectively. Parallelism of the slickenside and minor fold axis maxima precludes their contemporaneous formation and suggest that the minor folds have developed along predominantly dip-slip faults which later experienced strike slip. Nearly vertical slickensides from outcrops on Windam Hill Road, near Springhill, indicate dip-slip displacements.

\section{Cracked-pebble conglomerates}

A cracked-pebble conglomerate exposed on the coast of Chignecto Bay just north of the beach at Sand Cove provides convincing evidence for postdepositional deformation of the Ragged Reef Formation. Fracturing is confined to pebble clasts and usually occurs along steep, often irregular or plumose planes with very little lateral offset and no continuity with neighbouring pebbles. The strike of the cracked-pebble fractures shows a poorly developed east-southeast maxima, subparallel to the second joint set at Sand Cove (Fig. 2e).

The fractures likely resulted from the magnification of stresses inside competent pebbles contained in a ductile matrix (Eidelman and Reches, 1992), and commonly develop by point 
loading of pebbles during compression. Shearing along fractures is rare and can usually be related to later, more extensive fracture sets that displace both pebbles and matrix. However, the absence of subsequent offset suggests that pebble fracture development was a transient event little influenced by large fault displacements.

\section{Discussion}

During the Late Carboniferous, the western Cumberland Basin experienced rapid subsidence resulting in anomalously thick sequences of basin-fill strata (Ryan et al., 1987). In the Athol Syncline, 650 to $1000 \mathrm{~m}$ of Westphalian A-B Cumberland Group strata were deposited in as little as one million years (Calder, 1991). In comparison, a similar time-span of deposition during the Westphalian D is represented in the Sydney Basin of Cape Breton Island by only $150 \mathrm{~m}$ of the Sydney Mines Formation (Gibling and Bird, 1994). The thickness of the Cumberland Group contrasts with the relatively thin successions of Westphalian B strata preserved in other parts of the Maritimes Basin, where declines in net subsidence rates are represented in basin-fill sequences by cyclic, fanconglomeratic redbeds followed by finer-grained fluvial deposits (Ryan et al., 1987; Ryan and Zentilli, 1993). Thus, the Cumberland Basin, and the Athol Syncline in particular, formed an important early Westphalian depocentre within the Maritimes Basin during a period of regionally extensive erosion or non-deposition.

If diapirism of Windsor Group evaporites largely predated the Westphalian $B$, as suggested by stratigraphic relationships (Bell, 1944; Dolby, 1988) and paleoflow data (Gibling et al., 1992), relatively tight time constraints can be placed upon the syndepositional deformation of Cumberland Group strata. Dextral displacement contemporaneous with development of the Athol Syncline depocentre would have had to occur prior to the deposition of the Westphalian D Pictou Group which paraconformably to unconformably overlies Cumberland strata in the western Cumberland Basin (Bell, 1944; Ryan et al., 1991). Within the Cumberland Group, significant thickening of the Boss Point Formation towards the axis of the syncline in seismic profile (Calder and Bromley, in press), suggests that an important episode of basinal subsidence occurred during the Westphalian A. This is broadly coincident with a major episode of dextral transpression and thrusting documented in southern New Brunswick (Plint and van de Poll, 1984; Nance, 1987; Dallmeyer and Nance, 1990) and at Cape Chignecto (Waldron et al., 1989). The timing of post-depositional, sinistral deformation within the Athol Syncline is less well constrained, although much later extensional deformation in the southwestern Maritimes Basin is associated with the Mesozoic Fundy Rift.

Strike-slip deformation in Upper Carboniferous Cumberland Group strata of the western Cumberland Basin produced complex patterns of normal, reverse and oblique-slip faulting across the ASCFZ. Locally, this pattern likely reflects complex accommodation of large-scale displacement vectors by existing, weak material planes giving contrasting movement senses unrelated to the imposed boundary conditions. However, more regional patterns are attributed to changes in the sense of strike slip and the transpressional or transtensional nature of the accompanying deformation. Indeed, the ASCFZ probably wit- nessed an overall reversal in large-scale displacement vectors as tectonic adjustments occurred between the arrival of the Avalon Composite and Meguma terranes during the Late $\mathrm{Pa}$ leozoic, and the opening of the Fundy Rift during the Early Mesozoic.

While the general orientation of the ASCFZ is east-west, it is respectively marked to the east and west by northward and southward curving splays or bends. Depending upon the sense of strike slip, these deflections would have behaved as either releasing or restraining bends. Both scenarios are recorded in the deformation of Cumberland Group strata along the fault zone, in outcrop and in seismic section.

Significant dextral transpression, perhaps locally amplified by salt tectonics and related to post-accretionary motion between the Avalon Composite and Meguma terranes, occurred during the Late Carboniferous and resulted in the syndepositional deformation of basin-fill strata. Folding of Upper Carboniferous strata was accompanied by reverse faulting and thrusting necessary to accommodate regional compression. Subsequent, predominantly sinistral transtension resulted in the extensional deformation of these strata and the eventual offset of pre-existing transpressional structures.

Late Carboniferous deformation in the western Cumberland Basin mirrors that of the entire Maritimes Basin. The presence of major folds such as the Athol Syncline, and the geometry of the basin-fill, suggests that the western Cumberland Basin experienced regional compression that was synchronous with deposition during the Late Paleozoic. At this time, the western Cumberland Basin was within a dextral shear regime bounded to the south by synthetic dextral motion along the east-west Cobequid Fault, and to the west by possible antithetic sinistral motion along the northeast-southwest Harvey-Hopewell Fault. As wrench basins, the Athol Syncline and adjacent subparallel folds record the direction of regional compression during basin development. The alignment of these major folds within the basin suggests that regional compression occurred along a northwest-southeast axis in response to dextral movement on the ASCFZ which acted as a second-order zone of synthetic shear.

Minor fold axes at Clam Cove are nearly perpendicular to the slip directions of associated west-northwest-striking fault planes (as recorded by slickenside orientations) and may represent structures that developed at the same time as the subparallel Athol Syncline. This would imply that some of the nearly eastwest faults involved with early dextral transpression in the western Cumberland Basin outcrop on the coast of Chignecto Bay. Similarly, strike-slip faulting along the basin margins is inferred to have contributed significantly to the basin-fill (Ryan et al., 1987). However, most exposed faults probably formed as purely brittle structures after or during late stages of this transpressional episode.

Although destruction of the northern Cumberland Basin may be heralded by northward-prograding conglomerates of Lower Permian age on Prince Edward Island (van de Poll, 1989), most extensional deformation in the western Cumberland $\mathrm{Ba}$ sin is considered to be related to the opening of the Fundy Rift which reversed the sense of regional shear during the Middle Triassic (Ryan et al., 1987). Structures such as dextral en échelon folds offset sinistrally, and en échelon fold crests traversed by younger normal faults and grabens, are considered to be in- 
dicative of this change in sense of shear. The present configuration of the Athol Syncline and the Springhill Anticline is therefore considered to have resulted from the combined effects of initial, dextral transpression along the ASCFZ which produced the folds, and later sinistral transtension which may have offset the Athol Syncline and resulted in the development of major normal faults and graben structures across the crest of the Springhill Anticline. The creation of a sinistral shear regime during Middle Triassic rifting of the Bay of Fundy provides the most plausible mechanism for the extensional deformation of the western Cumberland Basin.

\section{SUMMARY}

Late Carboniferous transpression in the southwestern Maritimes Basin accompanied post-accretionary motion between the Avalon Composite and Meguma terranes, and was associated with a series of rapidly subsiding sedimentary sub-basins within the Cumberland Basin of northwestern Nova Scotia. The Athol Syncline is one such sub-basin and occupies much of the western Cumberland Basin where it is host to the largest economic coal resources in mainland Nova Scotia (Joggins and Springhill coalfields). Axial thickening of basin-fill strata confirmed by high-resolution seismic reflection profiles indicates that the syncline was a local depocentre during the Late Carboniferous, particularly for Westphalian B strata which are poorly represented in much of the Maritimes Basin.

Structural complications within the Athol Syncline, and truncation of its southern limb by the near-vertical, east-west Athol-Sand Cove Fault Zone (ASCFZ), are also substantiated in seismic profile. The zone of deformation associated with the ASCFZ is about $20 \mathrm{~km}$ wide and extends at least $150 \mathrm{~km}$ from the coast of Chignecto Bay to the Springhill coalfield. Changes in the sense of strike slip on the fault zone are recorded in numerous normal, reverse, and oblique-slip fault displacements of basin-fill strata.

Major Late Carboniferous strike-slip faults adjacent to the Athol Syncline include the dextral east-west Cobequid Fault to the south and the sinistral(?) northeast-southwest HarveyHopewell Fault to the northwest. These faults are respectively considered synthetic and antithetic structures within a regional dextral shear regime in which the Athol Syncline and other subparallel folds formed broadly perpendicular to the local vector of compression during basin development. The orientational maxima of minor fold structures associated with faults of the synthetic ASCFZ support this model. However, most deformation is extensional and reflects sinistral, post-depositional movement on the ASCFZ. Development of the Athol Syncline is therefore considered to have been controlled by dextral, syndepositional transpression across the ASCFZ during the Late Carboniferous, followed by sinistral transtension across the fault zone related to the Triassic opening of the Fundy half-graben.

\section{ACKNOWLEDGEMENTS}

Fieldwork for this project was funded by the Nova Scotia Department of Natural Resources. Comments by Walter van de Poll and constructive reviews by Bob Ryan and Joe White greatly improved the manuscript.
Barss, M.S. and Hacquebard, P.A. 1967. Age and the stratigraphy of the Pictou Group in the Maritime Provinces as revealed by fossil spores. In Geology of the Atlantic Region. Edited by E.R.W. Neale and $\mathrm{H}$. Williams. Geological Association of Canada, Special Paper 4 , pp. 267-282

BeLl, W.A. 1938. Springhill sheet, Cumberland and Colchester Counties, Nova Scotia. Geological Survey of Canada, Map 337 A

- 1944. Carboniferous rocks and fossil flora of northern Nova Scotia. Geological Survey of Canada, Memoir 238.

Bradley, D.C. 1982. Subsidence in Late Paleozoic basins in the Northern Appalachians. Tectonics, 1, pp. 107-123

CALDER, J.H. 1984. Structural features of the Springhill coalfield with notes on geology and mining history. Nova Scotia Department of Mines and Energy, Open File Report 578.

_- 1985. Depositional environment of the Westphalian B, Cumberland Basin coals of Springhill, Nova Scotia. In Report of Activities, Mines and Minerals Branch, 1984. Edited by K. Mills and J. Bates. Nova Scotia Department of Mines and Energy, Report 85-1, pp. 11-12.

1991. Controls on Westphalian peat accumulation, Springhill coalfield, Nova Scotia. Ph.D. thesis, Dalhousie University, Halifax, Nova Scotia, $310 \mathrm{p}$

CAlder, J.H. and Bromley, D.S. 1988. Structure and correlation of coal-bearing strata of the Athol Syncline, Cumberland Basin: results of recent seismic studies. In Mines and Minerals Branch Report of Activities 1988, Part A. Edited by D.R. MacDonald and Y. Brown. Nova Scotia Department of Mines and Energy, Report 88-3, pp. 9-13.

- - In press. Seismic stratigraphy of the Athol Syncline, Cumberland Basin: Implications for coal exploration. Geological Survey of Canada Paper.

DallmeYer, R.D. and NANCE, R.D. 1990. ${ }^{40} \mathrm{Ar} /{ }^{39} \mathrm{Ar}$ ages of detrital muscovite within early Paleozoic overstep sequences, Avalon composite terrane, southern New Brunswick: implications for extent of late Paleozoic tectonothermal overprint. Canadian Journal of Earth Sciences, 27, pp. 1209-1214

DolBY, G. 1988. Palynological analysis of samples from the Cumberland Basin and Cape Breton Island, Nova Scotia. Nova Scotia Department of Mines and Energy, Open File Report 88-033.

- 1991. The palynology of the Western Cumberland basin, Nova Scotia. Nova Scotia Department of Mines and Energy, Open File Report 91-006.

DonohoE, H.V., JR. and Wallace, P. 1985. Repeated orogeny, faulting and stratigraphy in the Cobequid Highlands, Avalon terrain of northern Nova Scotia. In "Fredericton 85". Edited by R.K. Pickerill, C.K. Mawer and L.R. Fyffe. Geological Association of Canada, Field Excursions, Volume II, 77 p.

Eidelman, A. and Reches, Z. 1992. Fractured pebbles: A new stress indicator. Geology, 20, pp. 307-310.

GibliNG, M.R. and BIRD, D.J. 1994. Late Carboniferous cyclothems and alluvial paleovalleys in the Sydney Basin, Nova Scotia. Geological Society of America Bulletin, 106, pp. 105-117

Gibling, M.R., Boenner, R.C., and Rust, B.R. 1987. The Sydney Basin of Atlantic Canada: an Upper Paleozoic strike-slip basin in a collisional setting. In Sedimentary Basins and Basin-forming Mechanisms. Edited by C. Beaumont and A.J. Tankard. Canadian Society of Petroleum Geologists, Memoir 12, pp. 269-285.

Gibling, M.R., Calder, J.H., Ryan, R., van De Poll, H., and Yeo, G.M 1992. Late Carboniferous and Early Permian drainage patterns in Atlantic Canada. Canadian Journal of Earth Sciences, 29, pp. 338-352.

Gussow, W.C. 1953. Carboniferous stratigraphy and structural geology of New Brunswick, Canada. American Association of Petroleum Geologists Bulletin, 37, pp. 1713-1816.

Hacquebard, P.A., Birmingham, T.F., and Donaldson, J.R. 1967. Pe- 
trography of Canadian coals in relation to environment of deposition. Energy Mines and Resources, Symposium on Science and Technology of Coal, Ottawa, pp. 84-97.

HARDING, T.P. 1985. Seismic characteristics and identification of negative flower structures, positive flower structures, and positive structural inversions. American Association of Petroleum Geologists Bulletin, 69, pp. 582-600.

Howie, R.D. and Cumming, L.M. 1963. Basement features of the Canadian Appalachians. Geological Survey of Canada, Bulletin 89.

KePPIE, J.D. 1982. The Minas Geofracture. In Major Structural Zones and Faults of the Northern Appalachians. Edited by P. St. Julian and J. Beland. Geological Association of Canada, Special Paper 24 , pp. 263-280.

1989. Northern Appalachian terranes and their accretionary history. In Terranes in the Circum-Atlantic Paleozoic Orogens. Edited by R.D. Dallmeyer. Geological Society of America, Special Paper 230, pp. 159-192.

MARTEL, A.T. 1987. Seismic stratigraphy and hydrocarbon potential of the strike-slip Sackville sub-basin, New Brunswick. In Sedimentary Basins and Basin-forming Mechanisms. Edited by C. Beaumont and A.J. Tankard. Canadian Society of Petroleum Geologists, Memoir 12, pp. 319-334.

McCuTcheon, S.R. and Robinson, P.T. 1987. Geological constraints on the genesis of the Maritimes Basin, Atlantic Canada. In Sedimentary Basins and Basin-forming Mechanisms. Edited by C. Beaumont and A.J. Tankard. Canadian Society of Petroleum Geologists, Memoir 12, pp. 287-297.

NANCE, R.D. 1987. Dextral transpression and Late Carboniferous sedimentation in the Fundy coastal zone of southern New Brunswick. In Sedimentary Basins and Basin-forming Mechanisms. Edited by C. Beaumont and A.J. Tankard. Canadian Society of Petroleum Geologists, Memoir 12, pp. 363-377.

Plint, A.G. and van De Poll, H.W. 1984. Structural and sedimentary history of the Quaco Head area, southern New Brunswick. Canadian Journal of Earth Sciences, 21, pp. 753-761.
Ryan, R.J. and Zentilli, M. 1993. Allocyclic and thermochronological constraints on the evolution of the Maritimes Basin of eastern Canada. Atlantic Geology, 29, pp. 187-197.

Ryan, R.J., Calder, J.H., Donohoe, H.V., JR., and Naylor, R. 1987. Late Paleozoic sedimentation and basin development adjacent to the Cobequid Highlands massif, eastern Canada. In Sedimentary Basins and Basin-forming Mechanisms. Edited by C. Beaumont and A.J. Tankard. Canadian Society of Petroleum Geologists, Memoir 12, pp. 311-317.

Ryan, R.J., Boehner, R.C., Deal, A., and Calder, J.H. 1990a. Cumberland Basin Geology Map: Amherst, Springhill and Parrsboro, Cumberland County. Scale 1:50,000. Nova Scotia Department of Mines and Energy, Map 90-12.

Ryan, R.J., Boehner, R.C., and Deal, A. 1990b. Cumberland Basin Geology Map: Oxford and Pugwash, Cumberland County. Scale 1:50,000. Nova Scotia Department of Mines and Energy, Map 90-13.

RyAN, R.J., BOEHNER, R.C., and CALDER, J.H. 1991. Lithostratigraphic revisions of the Upper Carboniferous to Lower Permian strata in the Cumberland Basin and their regional implications for the Maritimes Basin in Atlantic Canada. Bulletin of Canadian Petroleum Geology, 39, pp. 289-314.

SHAw, W.S. 1951. The Cumberland basin of deposition. Ph.D. thesis, Massachusetts Institute of Technology, Cambridge, Massachusetts, $107 \mathrm{p}$.

VAN DE Poll, H.W. 1989. Lithostratigraphy of the Prince Edward Island redbeds. Atlantic Geology, 25, pp. 23-35.

Waldron, J.W.F., Piper, D.J.W., and Pe-Piper, G. 1989. Deformation of the Cape Chignecto Pluton, Cobequid Highlands, Nova Scotia: thrusting at the Meguma-Avalon boundary. Atlantic Geology, 25, pp. 51-62.

WebB, G.W. 1963. Occurrence and exploration significance of strikeslip faults in southern New Brunswick, Canada. American Association of Petroleum Geologists Bulletin, 47, pp. 1904-1927. 